\title{
Hubungan antara Kadar Feritin dengan Malondialdehyde pada Pasien Talasemia $\beta$ Mayor di RSD dr. Soebandi Jember
}

\author{
(Correlation between Ferritin and Malondialdehyde Levels in \\ Major $\beta$ Thalassemia Patients at dr. Soebandi Hospital Jember)
}

\author{
Trinita Diyah Permatasari, Rini Riyanti, Desie Dwi Wisudanti \\ Fakultas Kedokteran, Universitas Jember \\ JI. Kalimantan 37, Jember 68121 \\ e-mail: riniriyanti.fk@unej.ac.id
}

\begin{abstract}
Repeated blood transfusions, increased iron absorption, and ineffective erythropoiesis in major $\beta$ thalassemia patients lead to iron overload characterized by elevated ferritin levels. Free iron will catalyze reactive oxygen species (ROS) formation by Fenton reaction that cause oxidative stress. Malondialdehyde (MDA) is the lipid peroxidation end product used to measure the oxidative stress. This study aimed to determine the correlation between ferritin levels and MDA levels in major $\beta$ thalassemia patients at dr. Soebandi Hospital Jember. An analitic observational study with cross sectional study design which the subjects were 15 patients with major $\beta$ thalassemia in the Pediatric Department at $d r$. Soebandi Hospital Jember who met inclusion and exclusion criteria. Ferritin levels measured by EnzymeLinked Fluorescent Immuno Assay (ELFA) method and MDA levels measured by Thiobarbituric Acid Reactive Substances (TBARS) method using spectrophotometer at $535 \mathrm{~nm}$. Data was analyzed with Shapiro Wilk normality test and Pearson correlation test. The mean of ferritin levels was 3540,46 $\pm 3925,37$ $\mathrm{ng} / \mathrm{mL}$ and MDA levels was $4,77 \pm 2,03 \mathrm{nmol} / \mathrm{mL}$. The result showed that there is strong positive correlation between ferritin levels and MDA levels with $p$ value $=0,001$ and $r=0,786$ in major $\beta$ thalassemia patients at dr. Soebandi Hospital Jember.
\end{abstract}

Keywords: major $\beta$ thalassemia, ferritin, MDA

\begin{abstract}
Abstrak
Transfusi berulang, peningkatan penyerapan zat besi, dan eritropoiesis inefektif pada pasien talasemia $\beta$ mayor menyebabkan kelebihan besi yang ditandai dengan peningkatan kadar feritin. Besi bebas akan mengkatalisasi pembentukan reactive oxygen species (ROS) melalui reaksi Fenton yang menyebabkan terjadinya stres oksidatif. Malondialdehyde (MDA) merupakan produk akhir peroksidasi lipid yang digunakan sebagai biomarker untuk menggambarkan derajat stres oksidatif. Penelitian ini bertujuan untuk mengetahui hubungan kadar feritin dengan kadar MDA pada pasien talasemia $\beta$ mayor di RSD dr. Soebandi Jember. Jenis penelitian ini adalah analitik observasional dengan desain cross sectional yang dilakukan pada 15 subjek pasien talasemia $\beta$ mayor di Laboratorium IImu Kesehatan Anak (IKA) RSD dr. Soebandi Jember yang memenuhi kriteria inklusi dan eksklusi. Kadar feritin diperiksa dengan metode Enzyme-Linked Fluorescent Immuno Assay (ELFA) dan kadar MDA diperiksa dengan metode Thiobarbituric Acid Reactive Substances (TBARS) menggunakan spektrofotometer dengan panjang gelombang $535 \mathrm{~nm}$. Dilakukan uji normalitas Shapiro-Wilk dan uji korelasi Pearson. Rata-rata kadar feritin $3540,46 \pm 3925,37 \mathrm{ng} / \mathrm{mL}$ dan rata-rata kadar MDA $4,77 \pm 2,03 \mathrm{nmol} / \mathrm{mL}$. Diperoleh nilai $p=0,001$ dan nilai $r=0,786$. Hal tersebut menunjukkan terdapat korelasi positif yang kuat antara kadar feritin dengan kadar MDA pada pasien talasemia $\beta$ mayor di RSD dr. Soebandi Jember.
\end{abstract}

Kata kunci: talasemia $\beta$ mayor, feritin, MDA 


\section{Pendahuluan}

Talasemia $\beta$ mayor adalah suatu kelainan darah herediter yang diturunkan secara autosomal resesif. Pada pasien talasemia $\beta$ mayor tidak terdapat sintesis rantai globin $\beta$ yang membentuk molekul hemoglobin manusia sehingga menyebabkan anemia hemolitik dan gangguan eritropoiesis [1,2]. Manifestasi klinis dari talasemia $\beta$ mayor muncul pada usia antara 2 sampai dengan 24 bulan dengan anemia berat dan membutuhkan transfusi sel darah merah secara rutin seumur hidup [3].

Prevalensi carrier talasemia di Indonesia mencapai $3-10 \%$ yang artinya 3-10 dari 100 orang merupakan carrier talasemia [4]. Jumlah kasus talasemia mayor di Indonesia mengalami peningkatan sejak tahun 2011 hingga 2015. Pada tahun 2011 kasus talasemia berjumlah 4.431 kasus dan pada tahun 2015 terdapat 7.029 kasus [5].

Pasien talasemia $\beta$ mayor membutuhkan transfusi darah secara rutin sepanjang hidup untuk mempertahankan kadar hemoglobin di atas 9-10,5 $\mathrm{gr} / \mathrm{dL}$ dengan tujuan menekan aktivitas eritropoiesis inefektif pada sumsum tulang serta mencegah terjadinya gangguan pertumbuhan. Akan tetapi, transfusi darah berulang dapat mengakibatkan kelebihan besi (iron overload) karena terjadi akumulasi besi secara terus-menerus sedangkan kemampuan tubuh untuk mengekskresikan besi sangat terbatas. Selain itu, kelebihan besi yang dialami oleh pasien talasemia $\beta$ mayor juga disebabkan karena peningkatan penyerapan besi pada saluran cerna akibat eritopoiesis yang tidak efektif. Kelebihan besi yang terakumulasi bersifat toksik untuk jaringan, dapat menyebabkan gagal jantung, sirosis, gangguan pertumbuhan, dan kelainan endokrin [6].

Feritin merupakan protein penyimpan besi yang utama. Pada keadaan kelebihan besi dan inflamasi, kadar feritin akan meningkat karena feritin juga termasuk protein fase akut [7]. Ketika kapasitas penyimpanan besi telah habis, besi bebas (free iron) pada pasien talasemia $\beta$ mayor akan mengkatalisasi pembentukan reactive oxygen species (ROS) yang sangat berbahaya seperti radikal hidroksil $\left(\mathrm{OH}^{-}\right)$yang berasal dari hidrogen peroksida melalui reaksi Fenton. Radikal hidroksil sangat reaktif, dengan reaksi awal yaitu peroksidasi komponen lipid, denaturasi protein, dan kemudian terjadi kerusakan DNA [8].

Jika produksi ROS melebihi kapasitas antioksidan, maka stres oksidatif akan terjadi [9]. Stres oksidatif dapat menyebabkan pemendekan umur eritrosit, amenore primer atau sekunder, hipogonadisme, gagal jantung, kerusakan hepar, kelainan endokrin, serta mortalitas pada pasien talasemia [10]. Peristiwa ini akan menghasilkan senyawa malondyaldehide (MDA) [11]. MDA merupakan suatu produk akhir peroksidasi lipid yang digunakan sebagai biomarker untuk menggambarkan derajat stres oksidatif [12].

Tujuan penelitian ini adalah mengetahui hubungan antara kadar feritin dengan kadar MDA pada pasien talasemia $\beta$ mayor di RSD $d r$. Soebandi Jember.

\section{Metode Penelitian}

Jenis penelitian ini adalah analitik observasional dengan desain cross sectional. Penelitian dilaksanakan di Laboratorium Biokimia Fakultas Kedokteran Universitas Jember, Laboratorium IImu Kesehatan Anak (IKA) dan Laboratorium Patologi Klinik Rumah Sakit Daerah (RSD) dr. Soebandi Jember pada Oktober-November 2017. Penelitian ini telah mendapatkan perijinan ethical clearance dari komisi etik Fakultas Kedokteran Universitas Jember dengan nomor ijin 1.159/H25.1.11/KE/ 2017.

Sampel penelitian adalah 15 pasien talasemia $\beta$ mayor dengan pengambilan sampel menggunakan metode purposive sampling berdasarkan kriteria inklusi yaitu pasien anak berusia 1-18 tahun yang telah memeriksakan diri dan terdiagnosis talasemia $\beta$ mayor, melakukan transfusi darah $\geq 2$ kali di Laboratorium IKA RSD dr. Soebandi, serta orang tua memberikan persetujuan untuk mengikuti penelitian dan kriteria eksklusi yaitu pasien demam ditandai peningkatan suhu $\geq 38^{\circ}$ $\mathrm{C}$, infeksi akut, inflamasi kronis, dan keganasan berdasarkan catatan medis dan pemeriksaan fisik.

Data primer diperoleh dari pemeriksaan kadar feritin dan kadar MDA yang dilakukan dalam satu waktu. Kadar feritin diperiksa dengan metode Enzyme-Linked Fluorescent Immuno Assay (ELFA) dan kadar MDA diperiksa dengan metode Thiobarbituric Acid Reactive Substances TBARS menggunakan spektrofotometer pada panjang gelombang $535 \mathrm{~nm}$. Sedangkan data sekunder diperoleh dari rekam medis serta buku jadwal transfusi pasien talasemia $\beta$ mayor. Dilakukan uji normalitas data untuk mengetahui distribusi data menggunakan uji Shapiro-Wilk. Analisis data untuk mengetahui korelasi antara kedua variabel menggunakan uji korelasi 
Pearson karena data terdistribusi normal. Nilai signifikansi $p<0,05$. Software yang digunakan adalah program komputer pengolah statistik Statistical Package for Social Science (SPSS) 16.0.

\section{Hasil}

Didapatkan 15 sampel pasien talasemia $\beta$ mayor yang memenuhi kriteria inklusi dan kriteria eksklusi. Karakteristik umum pasien talasemia $\beta$ mayor di RSD dr. Soebandi seperti pada Tabel 1.

Tabel 1. Karakteristik umum pasien talasemia $\beta$ mayor di RSD dr. Soebandi Jember

\begin{tabular}{|c|c|c|}
\hline $\begin{array}{l}\text { Karakteristik } \\
\text { Sampel }\end{array}$ & Jumlah (n) & Persentase (\%) \\
\hline $\begin{array}{l}\text { Jenis kelamin } \\
\text { Laki-laki } \\
\text { Perempuan }\end{array}$ & $\begin{array}{r}10 \\
5\end{array}$ & $\begin{array}{l}66,7 \% \\
33,3 \%\end{array}$ \\
\hline $\begin{array}{l}\text { Usia } \\
\qquad \begin{array}{l}0-5 \text { tahun } \\
6-15 \text { tahun } \\
>15 \text { tahun }\end{array}\end{array}$ & $\begin{array}{r}1 \\
10 \\
4\end{array}$ & $\begin{array}{r}6,7 \% \\
66,7 \% \\
26,7 \%\end{array}$ \\
\hline $\begin{array}{l}\text { Status Gizi } \\
\text { Gizi buruk } \\
\text { Gizi kurang } \\
\text { Gizi baik }\end{array}$ & $\begin{array}{l}5 \\
4 \\
6\end{array}$ & $\begin{array}{r}33,3 \% \\
26,7 \% \\
40,0 \%\end{array}$ \\
\hline $\begin{array}{l}\text { Suku } \\
\qquad \begin{array}{l}\text { Jawa } \\
\text { Madura }\end{array}\end{array}$ & $\begin{array}{r}14 \\
1\end{array}$ & $\begin{array}{r}93,3 \% \\
6,7 \%\end{array}$ \\
\hline $\begin{array}{l}\text { Kadar } \quad \mathrm{Hb} \\
\text { pretransfusi (gr/dL) } \\
\quad<4,0 \\
4,0-5,9 \\
6,0-7,9 \\
8,0-9,9 \\
\quad>10,0\end{array}$ & $\begin{array}{r}0 \\
4 \\
10 \\
1 \\
0\end{array}$ & $\begin{array}{r}0 \% \\
26,7 \% \\
66,7 \% \\
6,6 \% \\
0 \%\end{array}$ \\
\hline $\begin{array}{l}\text { Pemeriksaan } \\
\text { abdomen } \\
\quad \text { Splenomegali } \\
\quad \text { Hepatomegali } \\
\text { Hepatosplenomegal } \\
\text { i }\end{array}$ & $\begin{array}{l}7 \\
0 \\
8\end{array}$ & $\begin{array}{r}46,7 \% \\
0 \% \\
53,3 \%\end{array}$ \\
\hline $\begin{array}{l}\text { Total transfusi } \\
\text { darah } \\
\quad<20 \text { kali } \\
\geq 20 \text { kali }\end{array}$ & $\begin{array}{r}1 \\
14\end{array}$ & $\begin{array}{r}6,7 \% \\
93,3 \%\end{array}$ \\
\hline $\begin{array}{l}\text { Terapi kelasi } \\
\text { Deferiprone } \\
\text { (Feriprox) } \\
\text { Deferasirox } \\
\text { (Exjade) } \\
\text { Belum diterapi }\end{array}$ & $12 \begin{array}{l}2 \\
1\end{array}$ & $\begin{array}{c}13,3 \% \\
80,0 \% \\
6,7 \%\end{array}$ \\
\hline
\end{tabular}

Berdasarkan hasil penelitian didapatkan nilai rata-rata, nilai maksimal, dan nilai minimal kadar feritin dan MDA seperti pada Tabel 2. Hasil uji korelasi Pearson antara kadar feritin dengan kadar MDA seperti pada Tabel 3.

Tabel 2. Nilai kadar feritin dan kadar MDA

\begin{tabular}{|l|c|c|c|}
\hline \multicolumn{1}{|c|}{ Sampel } & $\begin{array}{c}\text { Rata- } \\
\text { rata } \pm \text { SD }\end{array}$ & Maks & Min \\
\hline $\begin{array}{l}\text { Kadar Feritin } \\
(\mathrm{ng} / \mathrm{mL})\end{array}$ & $\begin{array}{c}3540,46 \pm 39 \\
25,37\end{array}$ & 17194 & 873,9 \\
\hline $\begin{array}{l}\text { Kadar MDA } \\
(\mathrm{nmol} / \mathrm{mL})\end{array}$ & $4,77 \pm 2,03$ & 8,85 & 1,85 \\
\hline
\end{tabular}

Kadar feritin dan kadar MDA memiliki $p$ value $0,001<a \quad 0,05$ dan nilai $r$ sebesar 0,786 sehingga dapat disimpulkan kadar feritin dan kadar MDA memiliki korelasi yang bermakna dan korelasi yang kuat.

Tabel 3. Hasil uji korelasi Pearson kadar feritin dan kadar MDA

\begin{tabular}{|c|c|}
\hline & Kadar MDA \\
\hline \multirow{3}{*}{ Kadar Feritin } & r 0,786 \\
& p 0,001 \\
$\mathrm{n} 15$ \\
\hline
\end{tabular}

\section{Pembahasan}

Karakteristik sampel berdasarkan data yang diperoleh diketahui bahwa jumlah sampel laki-laki lebih banyak dari perempuan, yaitu 10 sampel $(66,7 \%)$ laki-laki dan 5 sampel $(33,3 \%)$ perempuan. Menurut hukum Mendel, talasemia diturunkan dari orang tua kepada anak secara autosomal resesif. Pola pewarisan autosomal resesif merupakan garis horizontal, sehingga dalam satu generasi ditemukan banyak penderita tetapi tidak untuk setiap generasi. Penderita talasemia $\beta$ mayor mendapat kemungkinan $25 \%$ dari kedua orangtua yang merupakan carrier [2]. Karakteristik sampel berdasarkan usia diperoleh jumlah sampel terbanyak berusia 6-15 tahun sebesar 10 sampel $(66,7 \%)$. Penderita talasemia $\beta$ mayor biasanya tampak normal pada saat lahir, gejala akan ditemukan pada anak-anak pada usia 2 tahun sampai dengan 6 tahun [6].

Karakteristik sampel menurut status gizi diperoleh sampel dengan status gizi buruk sebesar 5 sampel $(33,3 \%)$, gizi kurang sebesar 4 sampel $(26,7 \%)$, dan gizi baik sebesar 6 sampel $(40 \%)$. Pada pasien talasemia terjadi 
proses hemolisis sehingga terjadi anemia kronis yang mengakibatkan hipoksia jaringan. Hipoksia kronis menyebabkan gangguan penggunaan nutrien pada tingkat sel, sehingga terjadi gangguan pertumbuhan. Beratnya anemia dan hepatosplenomegali menyebabkan nafsu makan menurun, sehingga asupan makanan berkurang, berakibat terjadinya gangguan gizi [13]. Dari 15 sampel yang telah diteliti sebanyak 14 pasien talasemia $(93,3 \%)$ berasal dari suku Jawa dan dari 1 pasien talasemia $(6,7 \%)$ berasal dari suku Madura.

Berdasarkan data hasil penelitian pasien talasemia $\beta$ mayor terbanyak datang dengan kadar $\mathrm{Hb}$ pretransfusi $6,0-7,9 \mathrm{~g} / \mathrm{dL}$ sebesar 10 sampel $(66,7 \%)$ dan $99,3 \%$ dari jumlah sampel telah melakukan transfusi darah $\geq 20$ kali. Terapi transfusi darah yang direkomendasikan untuk pasien talasemia $\beta$ mayor yaitu transfusi darah rutin setiap dua sampai lima minggu sekali untuk mempertahankan kadar hemoglobin di atas 9$10,5 \mathrm{gr} / \mathrm{dL}$. Hal ini bertujuan untuk menekan aktivitas eritropoiesis inefektif pada sumsum tulang serta mencegah terjadinya gangguan pertumbuhan [6].

Karakteristik sampel menurut pemeriksaan abdomen ditemukan pasien talasemia $\beta$ mayor dengan splenomegali tanpa disertai hepatomegali sebesar 7 sampel $(46,7 \%)$ dan hepatosplenomegali sebesar 8 sampel $(53,3 \%)$. Splenomegali terjadi karena eritropoesis ekstrameduler [14]. Anemia berat pada pasien talasemia $\beta$ mayor menyebabkan ginjal melepaskan eritropoietin, hormon yang menstimulasi bone marrow untuk menghasilkan lebih banyak sel darah merah sehingga terjadi eritropoiesis inefektif. Eritropoiesis yang meningkat mengakibatkan hiperplasia dan ekspansi sumsum tulang, sehingga timbul deformitas pada tulang. Eritropoietin juga merangsang jaringan hematopoesis ekstrameduler di hati dan limpa sehingga timbul hepatosplenomegali [15]. Berdasarkan data yang diperoleh sebesar 12 sampel (80\%) mendapatkan terapi kelasi besi Deferasirox (Exjade) dan 2 sampel (13,3\%) mendapatkan terapi kelasi besi Deferiprone (Feriprox). Deferiprone efektif mengkelasi zat besi di jantung dibandingkan dengan penggunaan injeksi parenteral deferoksamin [16]. Deferasirox efektif mengkelasi besi di hepar dibandingkan dengan penggunaan Deferoksamin parenteral [17]. Selain itu, Deferasirox tidak memiliki efek samping besar sehingga dipakai secara luas [2]. Pada pasien talasemia $\beta$ mayor dengan transfusi darah berulang sangat diperlukan terapi kelasi besi [18]. Pemberian kelasi besi sebaiknya dimulai ketika kadar feritin meningkat di atas $1000 \mathrm{ng} / \mathrm{mL}$ atau pasien sudah mendapatkan 10-20 unit PRC [8].

Pada penelitian ini diketahui bahwa kadar feritin dari subjek bervariasi dengan rata-rata kadar feritin sebesar $3540,46 \pm 3925,37 \mathrm{ng} / \mathrm{mL}$. Kadar feritin terendah $873,9 \mathrm{ng} / \mathrm{mL}$ dan kadar feritin tertinggi $17194 \mathrm{ng} / \mathrm{mL}$. Kadar feritin subjek penelitian jauh di atas kisaran normal. Nilai normal feritin untuk laki-laki $12-300 \mathrm{ng} / \mathrm{mL}$ dan untuk perempuan $12-150 \mathrm{ng} / \mathrm{mL}$ [19]. Jika kadar feritin lebih dari nilai normal disebut kelebihan besi (iron overload) [20]. Sehingga bisa dikatakan bahwa pada subjek penelitian telah terjadi kelebihan besi. Kelebihan besi pada pasien talasemia $\beta$ mayor diakibatkan oleh transfusi darah yang berulang, eritropoiesis inefektif, dan peningkatan absorbsi besi melalui pencernaan sedangkan kemampuan tubuh sangat terbatas untuk mengeksresikan besi [6].

Dari hasil penelitian ini diperoleh bahwa rata-rata kadar MDA pada pasien talasemia $\beta$ mayor di RSD dr Soebandi Jember sebesar $4,77 \pm 2,03 \mathrm{nmol} / \mathrm{mL}$. Kadar MDA terendah 1,85 $\mathrm{nmol} / \mathrm{mL}$ sedangkan kadar MDA tertinggi 8,85 $\mathrm{nmol} / \mathrm{mL}$. Nilai normal kadar MDA adalah $<3,5$ $\mathrm{nmol} / \mathrm{mL}$ [21]. Subjek penelitian yang memiliki kadar MDA $\geq 3,5 \mathrm{nmol} / \mathrm{mL}$ sebanyak 10 orang. Maka dapat dikatakan telah terjadi peningkatan kadar MDA pada pasien talasemia $\beta$ mayor di RSD dr. Soebandi Jember. Hasil ini sesuai dengan penelitian sebelumnya pada 20 pasien talasemia $\beta$ mayor yang mengalami iron overload diperoleh rata-rata kadar MDA sebesar $6,69 \pm 0,9 \mathrm{nmol} / \mathrm{mL}$ [12]. Hal ini disebabkan karena pasien talasemia $\beta$ mayor mengalami penimbunan besi di dalam tubuhnya. Sebenarnya tubuh telah memiliki mekanisme penyimpanan besi melalui feritin yang dapat dilepaskan kembali untuk digunakan sesuai kebutuhan. Feritin ini akan mengikat besi, sehingga zat besi terionisasi $\left(\mathrm{Fe}^{2+}\right)$ tidak mencapai kadar toksik di dalam sel. Ketika kapasitas penyimpanan besi telah habis, besi bebas (free iron) akan mengkatalisasi pembentukan radikal hidroksil $(\mathrm{OH}-)$ berkonsentrasi tinggi dari komponen hidrogen peroksida melalui reaksi Fenton yang akan menyebabkan kerusakan membran, denaturasi protein, dan merusak replikasi DNA [12]. MDA merupakan produk akhir peroksidasi lipid yang dapat digunakan sebagai biomarker terjadinya stres oksidatif. Stres oksidatif inilah yang menyebabkan kerusakan pada hati, jantung, kelenjar endokrin, serta komplikasi neurologis 
pada pasien talasemia $\beta$ mayor [22].

Terapi yang didapatkan oleh pasien talasemia $\beta$ mayor selain transfusi darah secara rutin yaitu terapi kelasi untuk mengeksresikan besi, serta pemberian vitamin $\mathrm{C}$ maupun vitamin E yang digunakan sebagai antioksidan. Pemberian kelasi besi yang optimal dapat mengurangi deposit besi yang terjadi pada penderita talasemia [23]. Namun kurangnya kepatuhan untuk mengonsumsi obat kelasi besi yang diberikan dapat menjadi faktor yang menyebabkan terapi ini tidak optimal. Ketika transfusi darah berulang dilakukan tanpa mengonsumsi terapi kelasi besi secara teratur maka akan dapat menyebabkan peningkatan kadar feritin secara signifikan [24].

Hasil analisis data menggunakan uji korelasi Pearson kadar feritin dengan kadar MDA pada pasien talasemia $\beta$ mayor di RSD dr. Soebandi Jember diperoleh p-value 0,001 dan nilai $r$ sebesar 0,768 . Hal ini menunjukkan bahwa terdapat korelasi yang bermakna antara kadar feritin dengan kadar MDA serta memiliki korelasi yang kuat. Hal ini sesuai dengan penelitian sebelumnya yang menyebutkan bahwa peningkatan kadar feritin sebagai indikator kelebihan besi (iron overload) berhubungan dengan adanya kerusakan seluler pada penderita talasemia $\beta$ mayor melalui peningkatan kadar MDA [25].

\section{Simpulan dan Saran}

Terdapat hubungan yang bermakna antara kadar feritin dengan kadar MDA dengan nilai $p$ sebesar 0,001 serta kekuatan korelasi yang kuat $(r=0,786)$ pada pasien talasemia $\beta$ mayor di RSD dr. Soebandi Jember.

\section{Daftar Pustaka}

[1] Muncie HL, Campbel JS. Alpha and beta thalassemia. Am Fam Physician. 2009 Aug; 80(4): 339-344.

[2] Hoffbrand AV, Moss PAH. 2013. Kapita Selekta Hematologi. Edisi keenam. Jakarta: EGC; 2013.

[3] Galanello R, Origa R. Beta-thalassemia. OJRD. 2010; 5 (11): 1-15.

[4] Wahidiyat, I. 2006. Genetic Problems at Present and Their Challenges in the Future, Thalassemia as a Model. Paediatrica Indonesiana. [Internet] 2006 Oct [cited 2017 Jun 9];46(10):[189-194]. Available from: https://www.paediatricaindonesiana.org/ind ex.php/paediatricaindonesiana/article/view/ 927/768.

[5] Kementerian Kesehatan Republik Indonesia. [Internet]. Jakarta: Kementerian Kesehatan Republik Indonesia; 2017 [cited 2017 June 10]. Available from:http:/www.depkes.go.id/article/view/17 050900002/skriningpenting-untuk -cegahthalassemia.html.

[6] Cappellini MD, Cohen A, Porter J, Taher A, Viprakasit V. Guidelines for the management of transfusion dependent thalassemia (TDT). 3rd ed. Nicosia: Thalassaemia International Federation; 2014.

[7] Torti FM, Torti SV. Regulation of ferritin genes and protein. Blood. 2002 May; 99(10): 3505-3516.

[8] Prabhu R, Prabhu V, Prabhu RS. Iron overload in beta thalassemia. J Biosci Tech. 2009; 1(1): 20-31.

[9] Behrman EF, Kleigman RM, Jenson HB. Nelson textbook of pediatrics. 17th Ed. Philadelphia: WB Saunders; 2000.

[10] Mahdi EA. Relationship between oxidative stress and antioxidant status in beta thalassemia major patients. Acta Chim Pharm Indica. 2014 Aug; 4(3): 137-145.

[11] Suryohudoyo P. IImu Kedokteran Molekuler Kapita Selekta: Oksidan, Antioksidan, dan Radikal Bebas. Jakarta: Sagung Seto; 2000.

[12] Aziz BN, Al-Kataan MA, Ali WK. Lipid peroxidation and antioxidant status in $\beta$ thalassemic patients : Effect of Iron Overload. Iraqi J Pharm Sci. 2009 Jun; 18(2): 1-7.

[13] Arijanty L, Nasar SS. Masalah nutrisi pada thalassemia. Sari Pediatri. 2003 Jun; 5(1): 21-26.

[14] Andriastuti M, Sari TT, Wahidiyat PA, Putriasih SA. Kebutuhan transfusi darah pasca-splenektomi pada thalassemia mayor. Sari Pediatri. 2011 Dec; 13(4): 244249.

[15] Potts SJ, Mandleco BL. Pediatric nursing: caring for children and their families. 2nd ed. New York: Thomson Coorporatio; 2007. 
[16] Pepe A, Meloni A, Capra M, Cianciulli P, Prossomariti L, Malaventura $\mathrm{C}$, et al. Deferasirox, deferiprone, and desferrioxamine treatment in thalassemia major patients: cardiac iron and function comparison determined by quantitative magnetic resonance imaging. Haematologica. 2011 Jan; 96(1): 41-47.

[17] Neufeld EJ. Oral chelators deferasirox and deferiprone for transfusional iron overload in thalassemia major: new data, new questions. Blood. 2006 May; 107(9): 34363441.

[18] Permono HB, Ugrasena IDG. Buku Ajar Hematologi Onkologi Anak. Jakarta: IDAI; 2006.

[19] Departement of Nutrition for Health and Development WHO [Internet]. Geneva: Departement of Nutrition for Health and Development WHO; 2007 [cited 2017 Aug 10]. Available from: http://www.who.int/nutrition/publications/mic ronutrients/anaemia_iron_deficiency/97892 41596107.pdf

[20] World Health Organization [Internet]. Geneva: World Health Organization; 2011 [cited 2017 Nov 18]. Available from: http://www.who.int/vmnis/indicators/serum_f erritin.pdf
[21] Sengsuk C, Tangvarasittichai O, Chantanaskulwong $\mathrm{P}$, Pimanprom $\mathrm{A}$, Wantaneeyawong $S$, Choowet $A$, et al. Association of iron overload with oxidative stress, hepatic damage, and dyslipidemia in transfussion-dependent $\beta$-thalassemia/ $\mathrm{HbE}$ patients. India J Clin Biochem. 2014 Aug; 29(3): 298-305.

[22] Patne AB, Hisalkar PJ, Gaikwad SB, Patil $S V$. Alterations in antioxidant enzyme status with lipid peroxidation in B thalassemia major patients. Int $\mathrm{J}$ of Pharm \& Life Sci. 2012 Oct; 3(10): 2003-2006.

[23] Safitri R, Ernawaty J, Karim D. Hubungan kepatuhan transfusi dan konsumsi kelasi besi terhadap pertumbuhan anak dengan thalasemia. JOM. 2015 Oct; 2(2): 14741483.

[24] Satria A, Ridar E, Tampubolon L. Hubungan derajat klinis dengan kadar feritin penyandang thalassemia $\beta$ di RSUD Arifin Achmad. JOM FK. 2016 Oct; 3 (2): 19.

[25] Rasool M, Malik A, Jabbar U, Begum I, Qazi $\mathrm{MH}$, Asif M, et al. Effecy of iron overload on renal functions and oxidative stress in beta thalassemia patients. Saudi Med J. 2016 Aug; 37(11): 1239-1242. 